move him.

Blinded by the Sun is a remarkable play, and Poliakoff has produced two roles that de la Tour and Hodge clearly relish and in which they shine. Even some of the minor parts, such as the emeritus professor (Graham Crowden), are gems.

The science itself sits lightly on the plot, and might irritate the odd academic purist, but this hardly matters. It matters a little more that the issue of scientific fraud is not fully explored, and I was expecting that at some stage Christopher would be confronted and asked to explain why he cheated. Despite this omission, Poliakoff is to be congratulated on portraying chemists as real people, ill-equipped to wrestle with the complex pressures of a discipline in decline.

Fifty years ago, chemistry was in its ascendancy, and then it was lovingly portrayed by Alec Guinness in the Ealing comedy The Man in a White Suit. Since those heady days it has been almost ignored by writers and dramatists. Per-

\section{Choosing genes}

\section{Alan F. Wright and A. Christopher Boyd}

The Gift. A play by Nicola Baldwin. Currently touring in the UK until 2 November. Details from Y Touring, 8-10 Lennox Road, London N4 3NW, UK.

DISCOVERING ourselves is part of growing up, and for most it is not all good news. For the Kay family, the process is sudden and painful. Annie, a talented, athletic teenager, discovers she has the incurable, hereditary neurodegenerative disease Friedreich's ataxia. Her younger brother, Ryan, a "nerdy scruffbag with zits", wants to undergo the genetic test but is too young to be screened. The devastated Kays, as if to vent their fury at what for Annie is "a death sentence, no, worse, a life sentence", rally to Ryan's cause - the right to know. They win their case, and Ryan is found to be an unaffected carrier of Friedreich's ataxia.

The plot thickens when the action jumps ahead 15 years, and his wife also turns out to be a carrier, giving them a one-in-four risk of an affected child. Genetic profiling and in vitro fertilization are available, but she wants a child whose genetic constitution is determined by chance alone. Ryan, now a geneticist, deceives his wife (who eventually agreed to select out only Friedreich's ataxia) by choosing a particular disease-free embryo to fulfil not just his own but also his nowdead sister's dreams: a male predisposed to athleticism.

The action jumps a further 15 years to Ryan's son's horrified discovery of his genetic destiny. The ironic consequence haps if we had reached out to communicate better, they might have continued to be our allies, and we would not be in the unenviable position in which we now find ourselves.

Britain has more than 75 chemistry departments, all in theory able to do research and award PhDs. Many are under the pressures explored in Blinded By the Sun. Many are fated to close within the next ten years, unable to shake off their Elinors, unable to generate new funding for their Christophers, and unable to accommodate the success of their Als.

These are the real issues around which the play is built, not the apparent one of the unthinkable sin of scientific fraud. Perhaps Poliakoff set too many hares running, and this one got away, but that is a minor flaw in what is otherwise a superb play.

John Emsley is science writer in residence, Imperial College, London SW7 2AY, UK.

of the father's decision emerges - the son so hates the knowledge that his hard-won tennis achievements were predestined that he walks out on both his training and his father.

The Gift develops these themes to highlight the issues raised by our burgeoning knowledge of human genetics. Insights

\section{IMAGE UNAVAILABLE FOR COPYRIGHT REASONS}

\section{Annie Kay (Germaine Elliott).}

and quandaries are presented at every turn, yet the play manages to be funny, entertaining and deeply moving. The nonjudgemental line taken is especially commendable: while the characters represent a wide spectrum of opinion, the overall message is "you decide".

Commissioned by the Wellcome Centre for Medical Science, The Gift is aimed primarily at teenagers, but the issues raised are of such general concern that it deserves a wider audience. The play succeeds admirably both as pure theatre and in its aim to inform the public. No longer just an esoteric science, genetics concerns us all: it is about life and death, the meaning of and response to disability, and the new moral dilemmas created by increased knowledge.

At the end, the audience is drawn into debate and asked to vote on the extent to which genetic make-up should be a matter of choice. The all-too-short opportunity to challenge the characters, and an invited geneticist, is enthusiastically seized. The idea of selection against embryos carrying a fatal disease was finally accepted by Ryan's wife, but she would have had grave difficulties with less clear-cut choices. This was also the verdict of most of the audience.

The deliberate selection of human genes for complex traits such as athleticism is a distant prospect, but not wholly implausible; we know already that such selection would have dangerous and unpredictable consequences. As George Bernard Shaw allegedly said to Isadora Duncan, "but what if it has my looks and your brains?" In contrast, we already have formidable knowledge of genetic disease susceptibility. Some geneticists argue against the wide availability of screening for incurable disorders, but the public may demand "the right to know". As Annie says, "sometimes knowledge is a cure in itself", but it can be an agonizing one.

Widely lauded before and during its run at the Edinburgh Festival, The Gift $\approx$ played to packed halls. The audience was captivated and responded positively because the complex issues were so deftly handled. For some, the idea of a father choosing a genetic "gift" for his son is repellent; for others, it sends all the wrong messages.

Designer genes for successful living devalue the roles of social inheritance and personal freedom, and may even alienate the beneficiary: the son rejects the "gift" and leaves to forge his own destiny. The final irony is Ryan's admission that he could not contemplate the idea of selecting against Annie: "I wouldn't have changed a thing - except the rogue gene". The Gift is as much about relationships, disability, feelings and possibilities as it is about the genes that limit us. It serves as an inspiring model for future productions with similar aims, and is an education for us all.

Alan F. Wright and A. Christopher Boyd are in the MRC Human Genetics Unit, Western General Hospital, Crewe Road, Edinburgh EH4 2XU, UK. 